\title{
Research on the Community Participation Strategy of Luoshijiang Wetland Ecotourism
}

\author{
Mingqiang $\mathrm{Lu}^{1} \&$ Ning Wang ${ }^{1}$ \\ ${ }^{1}$ Qinhuangdao Branch of Northeast Petroleum University, Qinhuangdao 066004, China \\ Correspondence: Mingqiang Lu, Qinhuangdao Branch of Northeast Petroleum University 112 box, Qinhuangdao \\ city 066004, Hebei Province, China. E-mail: 324wxm@sian.com
}

Received: March 17, 2015 Accepted: April 4, 2015 Online Published: May 31, 2015

doi:10.5539/ijms.v7n3p120 URL: http://dx.doi.org/10.5539/ijms.v7n3p120

\begin{abstract}
Wetland ecotourism is a sustainable traveling form, and community participation is an important part of the development of wetland ecotourism. This study is based on detailed analysis on the current ecotourism participation situation in Luoshijiang wetland community, gives the community participation development strategy for ecotourism in Luoshijiang wetland, the studied strategy emphasis is expressed in three aspects: the first is how to extend the breadth and depth of ecotourism participation of community residents; the second is having ability construction to community residents at wetland; the third one is establishing reasonable benefit distribution mechanism to protect the benefit of peasants in community participation. The research is of great importance to control the ecological security of Erhai, Dali, promote economic development and social stability in the community, enrich ecotourism products and enhance the attractiveness of tourism.
\end{abstract}

Keywords: community participation; Luoshijiang wetland; ecotourism

\section{Introduction}

In the 1970s, western scholars began to pay attention to the effects of tourism on community. In China, relevant researches also start up. Peter E. Murphy (1985) stated the mutual effects between tourism industry and tourism zone. He proposed that the realization of coordinated development of community and tourism should be started from the four perspectives, i.e., accessibility environment, social culture, commercial economy and sound management. Wesche and Drum (1999) thought that community participation mode was closely related to degree of community participation. There were three modes: Community completely possessed and managed the tourism industry. Community and external commercial operators jointly develop community participation mode. Community takes the initiatives to take part in tourism development projects based on its own wills. In 1993, International Ecotourism Society defined ecotourism as "a traveling activity that undertakes dual responsibilities, i.e., protecting natural environment and maintaining local residents' livelihood" (Wu, 2009; Scheyens, 1999). The definition regards community participation as one important standard for inspecting ecotourism. Wetland's ecotourism, as a new and special tourism form, it focuses on protection of ecological environment and environmental education (Wang, 2009). It is a sustainable tourism form (Wang, 2011). As an important benefit group in the development of ecotourism site, farmers' high-quality tourism participation in the wetland community is of critical significance for the successful development of wetland tourism, promotion of environmental protection and facilitation of farmers' pursuit of wealth. Nevertheless, high-quality tourism participation requires that farmers in the wetland community should possess certain quality and professional skills (Chen, 2009; Sun, 2009).

Luoshijiang wetland is located in the northern part of Erhai, Dali. It is of great roles for the control on the ecological security of Erhai, Dali. In 2009, Erhai Management Bureau executed wetland recovery project in Luoshijiang River and founded Luoshijiang Wetland Development Co., Ltd. to develop wetland ecotourism. The wetland community is composed of four natural villages, i.e., Zhaoyi, Louyi, Shaping and Dongshaping. Besides, community self-governance center has been set up. More than $70 \%$ of the villagers are Bai Minorities. The traditional economic income comes from traditional cultivating industry, raising industry external labor. Due to the limited amount of family income, difference in each community's geographical location, traffic conditions and progress of new rural construction, the construction of communities, cultural construction and economic development are imbalanced. 
In order to ensure the coordinated development of environmental, economic and social benefits in the development of Laoshijiang wetland ecotourism, the research investigates into the community involved in Luoshijiang wetland ecotourism and analyzes the current situation of community participation. Moreover, based on this, the research constructs the community participation Strategy of Luoshijiang wetland Ecotourism. The research is of great importance to control the ecological security of Erhai, Dali, promote economic development and social stability in the community, enrich ecotourism products and enhance the attractiveness of tourism.

\section{The Analysis on the Current Situation of Community Participation and Ecotourism at Luoshijiang Wetland}

Currently, the main content of community participation is the reception of ecological tourists and agriculture production of wetland ecotourism, and there are plenty problems in the process of participating ecology.

(1). The number of participated people in the community is few, and the type is single

Currently, only part of community residents along national road 214 and Dali high way provide food, drink reception and accommodation for tourists. Luoshijiang wetland ecotourism and ecological sightseeing agriculture production haven't been implemented, and the community participation posts provided by wetland are few, which are mainly the production management of wetland.

(2). Community residents have high community participation enthusiasm, but weak participation ability

Community residents have certain understanding on the development of Luoshijiang wetland ecotourism and ecological sightseeing agriculture production, positively support and are eager to participate the construction and development of Luoshijiang wetland, and want to be rich drove by the development of wetland ecotourism and ecological sightseeing agriculture production, so they have high participation enthusiasm.

Currently, the overall community participation ability at Luoshijiang wetland is weak. Although they have the willing for community participation, their overall community participation awareness is weak, participating skill is weak, which cannot satisfy the development requirement of wetland ecotourism and ecological sightseeing agriculture production in the future.

Because of convenient transportation and active mind, the community participation awareness and ability of East Shangping Village and Shangping Village are slightly better than Zhaoyi Village and Louyi Village. Plenty villagers from Shangping Village are doing business and tourism commercial activity. Some of them are doing the business of petty commodities sale in travel traffic industry, travel catering reception and Dali ancient city, so they have relatively wide view, certain travel management ability and travel business ability, and the community participation ability is the strongest in these four natural villages at Luoshijiang wetland.

Most community residents at Luoshijiang wetland can do national features travel business, such as the manufacture of dairy fan, and they need to have production and sale training about traditional travel products series. Most of residents can have national dance and sing national songs, but they need to be organized to rehearse so as to well show to the customers. Most community residents at Luoshijiang wetland have traditional agricultural production skill, but they are not accordance in the requirements of intensification modern wetland agricultural production, and they must have the production and management skill training of modern wetland agriculture.

(3). The economic foundation of community residents is weak, and most community residents are lack of necessary start-up capital

The income source of most community residents is working, crop farming and breeding industry. Cow is the major income source of breeding industry, but the scale of breeding industry is small. Some of community resident plant orchid, but most of the behaviors are following the market and the plant scale and technical condition are limited, especially in recently years, the orchid market situation is fast falling down, only few of farmers made money form orchid planting. The annual household income that exceeds 30 thousand yuan is few, and community participation is lack of necessary start-up capital.

(4). Community benefit area is narrow

The construction of Luoshijinag wetland gave renting benefit to some of surrounding community residents, but because the ecological travel and ecological agriculture are in initial period, so the channels for community participation are few and the benefit area is narrows.

(5). Community participation management lags behind

There aren't professional community management organization and personnel: Luoshijiang Wet Lnad 
Development and Construction Co., Ltd. hasn't formulated relevant plans and regulations for encouraging and introducing community participation. Government doesn't have specific plans and regulations for protecting community participation, so the randomness is high.

\section{The Developing Strategy for Luoshijiang Wetland Community Participation}

(1). Readjusting industrial structure, developing wetland ecological travel and ecological sightseeing agriculture

Luoshijiang wetland is near Da-Li highway and 214 national road, so the transportation is convenient, which is only one hour drive from Xiaguan, the geographical location is good and the view of wetland is beautiful, so it has good resource condition and regional advantage. Developing wetland ecological travel, ecological sightseeing agriculture and other modern intensive industries can not only have the effect of protecting wetland, but also make wetland to have good economic and social benefit.

(2). Starting the construction project for community travel service ability to improve the participation ability strategy of farmers in the community

Starting the construction project for community travel service ability, hiring travel education and modern agricultural technical training organization to have knowledge trainings about modern production technology at wetland, wetland scientific knowledge, Agricola management skill, farming skills of wetland ecological agriculture, application skills for wetland playing facility, skills for tourists reception, re-innovation skill on traditional products, and others to community farmers can make famers to smoothly participate wetland travel and wetland ecological agriculture.

There is a big difference among community residents' economy and community participation ability in Luoshijiang wetland area, and in the process of community participation, this difference is allowed, so we can have positive guide to make community residents to choose the community participation method, which is in accordance with their family and ability.

(3). Elitist strategy by emphasizing part of the community

To those community elitists who have wide and new view and thought, were trained by modern industrialization train, have a skill and feasible participation plans, the government can support them by investing guiding capital, give them soft loan and other forms to make them to have good leading role ad example effect.

(4). Strategy for constructing complete community travel infrastructure

At first, we shall complete the tourism traffic condition in the community by extending the traffic line in the village for connecting Zhaoyi Village with Da-Li highway and 214 national road, getting through the travel branches inside the villages, and developing special and convenient tourism vehicles. Secondly, we shall perfect the tourism accommodation and catering facility in villages, especially the places near wetland and have good views, and we can develop special tourism reception facility. Thirdly, we will complete the water, electricity, communication and other infrastructures in villages to ensure the normal operation of community travel. At last, we can construct tourist service points to make it convenient for tourists to get various travel information.

\section{(5). The strategy for establishing reasonable travel benefit distribution mechanism}

Reasonable benefit distribution mechanism is the important protection for the sustainable development of Luoshijiang wetland. In Luoshijiang wetland community, plenty community residents are not clear about community participation, and the foundation of tourism development hasn't been founded, so in benefit distribution mechanism, we shall change "transfusion" to "hematopoiesis", encourage community residents to have various community participation through the idea adjustment of themselves and the obtaining of legal right and benefit, and inject power for the sustainable development of set land tourism.

(1) With the development of Luoshijiang Wetland Development and Construction Co., Ltd., we will continue to absorb community residents in wetland to enter the enterprise and work on some foundation things for wetland, select some staff with strong working ability to enter the management of the enterprise, give priority to farmers who rented land to the company, gradually extend community benefit area of wetland, and improve the benefit degree of wetland community.

(2) We will pay enough renting fee for the land in wetland community in time, and the renting fee will be changed every ten year by the factors of rising prices and so on, but the premise is not lower than the land farming benefit of farmers at the same period.

(3) Encouraging villagers to protect and remould tradition. The government can provided constructive material and model houses for remoulding based on consulting the opinions of villagers. 
(4) The company shall consider about constructing sale base for tourism products and native products around wetland, and rent it to community residents whose land was rented in low price or free so as to provide employment opportunities and economic benefit to residents who don't have land.

(5) We will provide free employment training, which is leaded by Erhai protection and management bureau, specifically organized by community self-control center of village committee, and donated by the company, so that the villagers can select song and dance performance, catering, room service, guidance, outdoor guide, the production technology of tourist souvenir, modern agricultural production technology, and other training items by themselves.

(6) In the future, when the wetland ecotourism and ecological agriculture are developed, we must consider the benefit of residents in the community, especially the community residents who didn't directly participate, and protect their tourism profit by secondary allocation of benefit.

(6). The developing strategy of "nonparticipation is the biggest participation"

Because the community residents in Luoshijiang wetland are plenty, but the developing scale of the company is limited, by the current condition, it's impossible to provide direct employment opportunity for all the community residents, so many residents still need to do traditional agricultural and fishery activity. The tradition idyllic scenery, Bai nationality folk custom, the life and production scene in wetland community is the important resource for the development of wetland tourism, so we shall try our best to protect the reality and neutrality of community, and implement green development, sustainable development in the whole tourism area, and establish complete cultural and ecological village. If the whole place is involved on a large scale, the tourist attraction of the community will be deduced. So the nonparticipation of some community residents in Luoshijiang wetland, in the other angle, is a kind of participation but an indirect participation, which will provide background and support for the development of ecological industry in Luoshijiang wetland.

This indirect participation mainly contains two aspects of scene construction of wetland community the industry interaction among community residents. The landscape construction in Luoshijiang wetland community means that the community residents in Luoshijiang wetland shall keep the traditional Bai nationality (Bai nationality and Erhai) idea, traditional farming life, traditional fishery life around Erhai, fishing method, traditional Bai nationality custom. Keeping civilization, unsophisticated community atmosphere, friendly relation among residents, and maintain of rustic relation can strengthen the good expression of tourists to the sightseeing place, produce favorable word-of-mouth effect, and become the optimum background for the development of ecotourism and sightseeing agriculture in Luoshijiang wetland. Industry interaction means that the residents in Luoshijiang wetland community can directly provide travel primary product to residents who participated, and have indirect participation. For example, the southwest part of Shaping Village and northwest part of Louyi Village is far from wetland, and the view effect is bad, which belong to the communities that have difficulties in participating wetland ecotourism, but they can develop crop farming and breeding industry to provide local chicken, pigs, Erhai fish and other original agricultural and sideline products to Dongshaping and Zhaoyi Village for directly participating tourists reception, and form industry interaction support.

\section{Conclusion}

This study is based on detailed analysis on the current ecotourism participation situation in Luoshijiang wetland community, gives the community participation development strategy for ecotourism in Luoshijiang wetland, the studied strategy emphasis is expressed in three aspects: the first is how to extend the breadth and depth of ecotourism participation of community residents; the second is having ability construction to community residents at wetland; the third one is establishing reasonable benefit distribution mechanism to protect the benefit of peasants in community participation.

\section{References}

Chen, Z. Y., \& Yang, G. H. (2009). Route selection of the community-dominated tourism development model in poverty-stricken minority region with abundant tourism resources: a case study on Yubeng Zang Minority Community in Meili avalanche scenic spot of Yunnan. Hei longjiang National Series, (2), 52-63.

Drumm, W. R. A. (1999). Defending the Rainforest, Action Amazonia (pp. 148-156). New York: Quito, Ecuad. Murphy, P. E. (1985). Tourism: A community Approach (pp. 12-34). New York and London: Thomson Learning.

Scheyens, R. (1999). Ecotourism and the empowerment of local communities. Tourism Management, 20, 245-249. http://dx.doi.org/10.1016/S0261-5177(98)00069-7

Sun, J. X. (2009). Tourist Anthropology Analysis on Community Tourism and Community Participation (pp. 
90-152). Beijing: The Commercial Press.

Wang, J., \& Wang, Y. (2011). Community Participation Patterns in Ecotourism Development of Wetland Nature Reserve in Jiangsu Province: A Case Study in the Jiangsu Wetland Nature Reserve. Resources Science, 33(11), 2175-2181.

Wang, L. L., \& Lu, L. (2009). Research progress on wetland ecotourism. Chinese Journal of Applied Ecology, 20(6), 1517-1524.

Wu, C. C., Wu, Z. W., Zhang, Q. M., Hu, W. H., \& Tan, Y. M. (2009). An atomization of the definition of ecotourism. Journal of Central South University of Forestry \& Technology, 29(5), 1-7.

\section{Copyrights}

Copyright for this article is retained by the author(s), with first publication rights granted to the journal.

This is an open-access article distributed under the terms and conditions of the Creative Commons Attribution license (http://creativecommons.org/licenses/by/3.0/). 